\title{
TRADISI MUJAHADAH: METODE MENJAGA HAFALAN AL-QUR'AN DI PONDOK PESANTREN AL-ITTIFAQIAH, INDRALAYA, INDONESIA
}

\author{
Muhammad Amin \\ IAIN Syaikh Abdurrahman Siddik Bangka Belitung, amin.kbalid@iainsasbabel.ac.id
}

\begin{tabular}{|c|c|c|}
\hline Diterima: 27 April 2020 & Direvisi : 23 Juni 2020 & Diterbitkan: 30 Juni 2020 \\
\hline
\end{tabular}

\begin{abstract}
The phenomenon of memorizing scripture increasingly became the mainstream of Indonesian religious culture with the growth of various tahfidz programs and the broadcast of tahfidz events on national TV. However, Prophet Muhammad has indicated the difficulty of maintaining al-Qur'an since the 7th century $A D$, and it has remained nowadays. As the answer to this problem, the author conducted an ethnographic study by examining the tradition of mujahadah in Al-Ittifaqiah Islamic Boarding School with there kinds of mujahadah. Mujahadah Ula is a form of quality control on the recitation of a student by means of rotating by five coaches, mujahadah tsaniah is a form of habituation where students are required to fasting 40 days and always recite the whole al-Qur'an with memorization every day, while mujahadah tsalitsah is a form Confirmation of where students will be tested for 15 hours reciting 30 chapters of alQuran with memorization and listened by the students and coaches in a special majlis.
\end{abstract}

Keywords: Mujahadah, Tahfidz al-Qur'an, Al-Ittifaqiah Islamic Boarding School

\begin{abstract}
Abstrak
Fenomena menghafal kitab suci semakin menjadi tren budaya religi di Indonesia dengan lahirnya berbagai macam program tahfid dan disiarkannya acara-acara tahfid di TV lokal dan nasional. Akan tetapi, secara normatif-teologis, Nabi Muhammad saw. mengindikasikan sulitnya menjaga hafalan al-Qur'an sejak abad ke-7 $\mathrm{M}$ dan hal itu tetap terjadi hingga saat ini. Untuk menjawab masalah ini, penulis melakukan kajian etnografi dengan meneliti tradisi mujahadah di Pondok Pesantren Al-Ittifaqiah dengan tiga tingkatan mujahadah. Mujabadah Ula merupakan bentuk quality-control terhadap hafalan santri dengan cara disimak bergilir oleh lima pembina, mujahadah tsaniah adalah bentuk pembiasaan dimana seorang santri dituntut untuk berpuasa selama 40 hari dan setiap hari senantiasa mengkhatamkan al-Qur'an bil gaib, sementara mujahadah tsalitsah adalah bentuk konfirmasi dimana seorang santri akan diuji selama 15 jam membaca al-Quran sebanyak 30 Juz bil gaib dan disimak oleh para santri dan pembina dalam majlis khusus.
\end{abstract}

Kata Kunci: Mujahadah, Tahfidz, al-Qur'an, Pondok Pesantren Al-Ittifaqiah (PPI) 


\section{PENDAHULUAN}

Menghafal kitab suci menjadi satu tren pendidikan di Indonesia pada dekade terakhir. ${ }^{1}$ Berbagai macam metode penghafalan al-Quran dan juga program-program tabfidz, unggulan semakin bermunculan. ${ }^{2}$ Akan tetapi, secara teologis-normatif, Nabi Muhammad saw. mengkonfirmasi kesulitan dalam menjaga hafalan al-Qur'an, bukan dalam menghafalnya. ${ }^{3}$ Sebagai jawaban dari problem mendasar ini, Pondok pesantren Al-Ittifaqiah (PPI), terletak di Indralaya Ogan Ilir Sumatera Selatan Indonesia, menerapkan sebuah metode alternatif dalam menjaga hafalan al-Quran yakni metode mujahadah tahfidz al-Qur'an. ${ }^{4}$

Selain menjadi tren pendidikan, penghafalan kitab suci juga menjadi media tontonan dengan banyaknya acara TV di

1 Ali Romadoni mengklasifikasi golongan penghafal al-Quran di Indonesia menjadi tiga golongan yaitu penghafal al-Quran yang mengkajinya secara kritis, penghafal al-Quran yang menjadikan predikat hafidz sebagai orientasi akhir, penghafal al-Quran yang menjadikan proses menghafal sebagai ibadah. Lihat penjelasan lebih jauh dalam Ali Romadoni, "Tradisi Hafalan Qur'an Di Masyarakat Indonesia," Journal of Qur'an and Hadith Studies 4, no. 1 (2015): 14.

2 Terdapat banyak sekali metode menghafal dan menjaga hafalan al-Quran seperti metode wahdah (menghafal mandiri), talaqqi (menghafal di hadapan seorang guru), takrir (mengulang-ulang hafalan), dan tasmi' (menyimakkan hafalan) yang diterapkan di Pondok Pesantren Qudratullah, Banyu Asin, Sumatera Selatan. Lihat Hikmawati, "Bimbingan Tahfidz Al-Quran: Studi Tentang Stategi Penghafal Al-Qur'an Di Pondok Pesantren Qudratullah KM. 35 Langkan Kabupaten Banyu Asin"”, (UIN Raden Fatah Palembang, 2013)., hlm. 98 - 99.

3 Abu Abdillah Muhammad ibn Isma'il AlBukhari, Al-Musnad Al-Shahih Al-Mukbtashar Min Umuri Rasulillah Saw Wa Sunanibi Wa Ayyamibi, Vol. VI (Beirut: Dar Thauq An-Najah, 1422)., hlm. 193.

4 Penulis menggunakan terma 'alternatif' berdasarkan penelitian penulis sebelumnya tentang sejarah lahirnya tradisi mujahadah di pondok pesantren Al-Ittifaqiah. Berdasarkan kajian penulis, tradisi ini lahir sebagai bentuk eksternalisasi dan proses kreatif para guru tabfidz di AlIttifaqiah berdasarkan akumulasi pengalaman yang mereka peroleh di tempat asalnya. Lihat Muhammad Amin, "Tradisi Mujahadah Tahfidz Al-Quran Di Pondok Pesantren Al-Ittifaqiah Indralaya Ogan Ilir Sumatera Selatan (Analisis Living Quran)," Dirosat: Journal of Islamic Studies 2, no. 2 (2017): 138-44. Lihat juga LEMTATIQI, Mengenal Lembaga Tabfidh Tilawah Dan Ilmu Al-Qur'an Allttifaqiah, (Indralaya: Ittifaqiah Press, 2006)., hlm. 50.
Indonesia yang menyiarkan perlombaan menghafal al-Quran, anak-anak, remaja, maupun dewasa. ${ }^{5}$ Berbagai macam metode penghafalan pun dikembangkan dan sayangnya tidak menyertakan metode menjaga hafalan. ${ }^{6}$ Sementara itu, secara normatif-teologis, Nabi Muhammad saw. mengingatkan adanya kesulitan dalam menjaga hafalan al-Qur'an, bukan menghafalnya. Hal ini sebagaimana dijelaskan dalam sabdanya: ${ }^{7}$

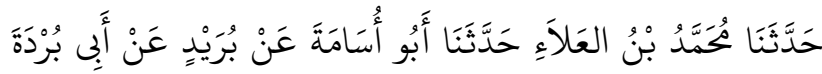

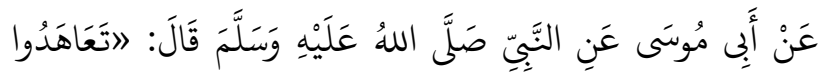

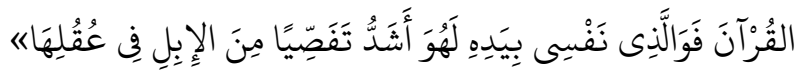
Artinya: Telah menceritakan kepada kami Muhammad bin al-'Ala', telah menceritakan kepada kami Abu Usamah dari Buraid dari Abu Burdah dari Abu Musa dari Nabi saw., beliau bersabda: "Peliharalah selalu al-Qur'an, demi Dzat yang jiwaku berada di tangan-Nya, sungguh ia lebih cepat hilang daripada unta yang terikat.

Kesulitan dalam menjaga hafalan inilah yang memicu dibentuknya metode mujahadah tabfidz al-Qur'an di PPI dengan tiga tingkatan yaitu mujahadah ula (tingkat pertama), mujahadah tsaniah (tingkat kedua), dan mujahadah tsalitsah (tingkat ketiga). Secara singkat, mujahadah tabfidz al-Qur'an berarti usaha sungguh-sungguh yang dilakukan

5 Hayati menyoroti fenomena ini, khususnya di Sumatera Barat, dan menjelaskan bahwa hal ini didasari oleh adanya komitmen seorang muslim terhadap pedoman hidup serta adanya motivasi lain seperti meningkatnya IQ dan kecerdasan. Lihat Hayati, Nurhasanah, and Oktarina Yusra, "Fenomena Lansia Menghafal Al-Quran Pada Majelis Al-Quran Di Kec. Salimpaung Kab. Tanah Datar Sumatera Barat," Fuaduna: Jurnal Kajian Keagamaan Dan Kemasyarakatan 02, no. 02 (2018): 64-65. Lihat juga Muhammad Taufik, "Studi Al-Qur'an Sebagai PemicuPemacu Peradaban: Telaah Sosio-Hostoris," Fuaduna: Jurnal Kajian Keagamaan Dan Kemasyarakatan 03, no. 02 (2019): 134-35.

${ }^{6}$ Lihat berbagai metode tersebut dalam Anna M. Gade, Perfection Makes Practice: Learning, Emotion, and the Recited Quran in Indoensia (USA: University of Hawai, 2004)., hlm. $60-113$.

7 Al-Bukhari, Al-Musnad Al-Shabih Al-Mukbtashar Min Umuri Rasulillab Saw Wa Sunanibi Wa Ayyamibi., Vol. VI, hlm. 193. 
oleh para penghafal al-Qur'an dalam menjaga dan memperbaiki hafalannya setiap hari.

Maka melalui artikel ini, penulis memaparkan secara deskriptif-analitis ketiga tingkatan tersebut. Tujuannya adalah memperkenalkan metode mujahadah sebagai sebuah metode pendidikan alternatif yang berkualitas dalam menghafal dan menjaga kitab suci sehingga menjadi tawaran metodologis aplikatif yang dapat diterapkan dimana saja dengan berbagai modifikasinya.

Penelitian ini merupakan penelitian lapangan (field research) dan didukung dengan sumber-sumber kepustakaan sebagai bahan penjelas dari fenomena dan tradisi yang dikaji. Kajian ini bersifat kualitatif dan dengan menampilkan hasil analisis dengan bentuk deskriptif-analitis. ${ }^{8}$ Pendekatan yang digunakan dalam penelitian ini adalah pendekatan etnografis. Pendekatan etnografis digunakan sebagai alat dalam mengungkap makna emic dari penduduk asli pemilik tradisi.?

Penelitian ini dilakukan di Pondok Pesantren Al-Ittifaqiah, Jalan Lintas Timur, KM. 36, Indralaya, Ogan Ilir, Sumatera Selatan sebagai pesantren Tabfidz yang memperkenalkan tradisi mujahadah. Penulis melakukan penelitian sejak bulan Oktober 2016 sampai februari 2017. Setelah melakukan penelitian di pondok pesantren Al-Ittifaqiah, penulis mendapatkan informasi bahwa embrio tradisi ini berada di Pondok Pesantren An-Nur Yogyakarta, hal ini juga diperkuat dengan temuan penulis bahwa sebagian besar tenaga pengajar tahfidz di Lembagai Tahfidz Tilawah dan Ilmu Al-Quran Al-Ittifaqiah (Selanjutnya disingkat LEMTATIQI) memiliki syahādah dari Pondok-Pesantren An-

${ }^{8}$ Lihat Nyoman Kutha Ratna, Metodologi Penelitian: Kajian Budaya Dan Ilmu Sosial Humainiora Pada Umumnya No Title (Yogyakarta: Pustaka Pelajar, 2010)., hlm. 89 - 105. Lihat juga Lexy J. Moelong, Metodologi Penelitian Kualitatif No Title (Bandung: Rosdakarya, 2016)., hlm. 6.

9 Koentjaraningrat, Pengantar Ilmu Antropologi (Jakarta: Rineka Cipta, 2009)., hlm. 57.
Nur (PP. An-Nur), ${ }^{10}$ Ngrukem, Bantul, Yogyakarta. ${ }^{11}$ Tenaga pengajar tabfidz LEMTATIQI saat ini berjumlah 29 orang. Empat di antaranya berasal dari PP. An-Nur yaitu ustadz Royani Abdul Mudi (Ketua LEMTATIQI), ustadz Zainal Abidin, ustadzah Ummi Rosyidah, dan ustadzah Muyasaroh.

Berdasarkan temuan awal tersebut, penulis melacak akar tradisi ini ke pondok pesantren An-Nur, Ngrukem, Bantul Yogyakarta pada bulan Maret 2017. Hasil penelitian penulis tentang bagaimana hubungan kedua pondok pesantren ini dan proses pembentukan tradisi mujahadah dapat dirujuk pada artikel yang telah dipublikasikan terlebih dahulu. ${ }^{12}$

Subjek penelitian dan sumber data utama dalam penelitian ini adalah para pengasuh LEMTATIQI dan juga santriwan dan santriwati yang telah atau akan melaksanakan program mujāhadah. Program mujahadah adalah rangkaian kegiatan yang wajib diikuti oleh santri yang telah menyelesaikan hafalan al-Qurannya untuk memperkuat hafalan tersebut. Maka untuk mendapatkan data terkait mujahadah, maka penulis menentukan informan yang diwawancarai dari kalangan pimpinan pesantren, Pembina tahfidz, santri dan alumni.

Di antara pengasuh yang penulis wawancarai adalah: KH. Mudriq Qori sebagai pimpinan PPI saat ini, Ahmad Royani Abdul Mudi sebagai ketua LEMTATIQI, Muyasaroh sebagai pembina LEMTATIQI, KH. Muslim Nawawi sebagai pengasuh PP. An-Nur, serta beberapa santri yang telah menyelesaikan program mujāhadah seperti Wahyudi sebagai alumni LEMTATIQI yang telah menyelesaikan

10 Profil PP. An-Nur dapat dilihat dalam Taufik and Dkk, Kumpulan Drikir Dan Do'a Kafa Bibi (Bantul: Pondok Pesantren An-Nur, 2015)., hlm. vii - ix.

11 Data tersebut didapatkan berdasarkan keterangan ustadzah Muyasaroh (50 tahun), tenaga pengajar LEMTATIQI, melalui pesan singkat pada tanggal 20 Oktober 2016.

12 Lihat Amin, "Tradisi Mujahadah Tahfidz AlQuran Di Pondok Pesantren Al-Ittifaqiah Indralaya Ogan Ilir Sumatera Selatan (Analisis Living Quran)." Dirosat: Journal of Islamic Studies, Vol. 2 No. 2, 2017. 
mujāhadah ūlā, Daria dan Meni Diana yang telah menyelesaikan mujāhadah saniah dan mujāhadah salisah.

\section{TRADISI MUJAHADAH: TIGA TINGKATAN PENJAGAAN HAFALAN AL-QUR'AN}

\section{Ruang Lingkup Mujahadah Tahfidz al- Quran: Dimensi Ontologis}

Secara etiomologis, kata mujähadah berarti perjuangan atau jihad. ${ }^{13}$ Asal katanya dari bahasa Arab yaitu Jāhada - Yujähidu yang berarti mengerahkan segala kemampuan. ${ }^{14}$ Menurut Ibn Fāris, kata ini memiliki arti asal yaitu kesulitan dan kesungguhan. ${ }^{15}$ Dalam ilmu Tasawwuf, kata mujähadah diartikan sebagai perjuangan seorang hamba dalam melawan hawa nafsu dan lingkungannya untuk memperoleh kedekatan dengan khaliq-nya. ${ }^{16} \quad$ Sementara al-Gazali mengartikan mujähadah sebagai usaha sungguhsungguh untuk mendekatkan diri kepada Allah. ${ }^{17}$

Kata tahfiz merupakan bentuk mașdar dari kata haffaza - yuhaffizu - tahfizan yang berarti penghafalan atau latihan menghafal. ${ }^{18}$ Kata tersebut merupakan bentuk suläsi mazìd bi harfin dari kata hafiza - yahfazu hifżan yang berarti menjaga, memelihara, dan melindungi sesuatu

13 Atabik Ali and Ahmad Zuhdi Muhdlor, Kamus Al-Ashri (Yogyakarta: Multi Karya Grafika, 1996)., hlm. 1628. Dalam bahasa Inggris, kata ini diartikan sebagai struggle againts difficulties; war againts the infidels. Lihat F. Steingass, Arabic - English Dictionary (New Delhi: Cosmo Publication, 1978)., hlm. 250.

${ }^{14}$ Ahmad Warson Munawwir, Al-Munawnir: Kamus Arab - Indonesia (Surabaya: Pustaka Progressif, 1997)., hlm. 217. Kata ini terulang sebanyak 41 kali dalam al-Quran. Lihat Muhammad Fu'ād 'Abd Al-Bāqi, Al-Mu'jam AlMufahras Li Alfadzi Al-Qur'an (Beirut: Dar al-Fikr, 1994)., hlm. $232-233$.

15 Zakariyya ibn Fāris, Mu’jam Al-Maqāyìs Fi AlLughah (Beirut: Dar al-Fikr, 1994)., hlm. 227. Bandingkan dengan Rāgīb Al-Aṣfahāni, Mu’jam Al-Mufradāt Fì Garìb AlQur'an (Beirut: Dar al-Qalam, 1412)., hlm. 198.

16 Asmaran As, Pengantar Studi Tasawnuf (Jakarta: Raja Grafindo Persada, 1996)., hlm. 377

17 Abū Hāmid Al-Gazāliy, Ibyà' 'Ulūm Al-Dìn, V (Kairo: Dar al-Hadits, n.d.)., hlm. 60.

18 Ali and Muhdlor, Kamus Al-Ashri., hlm. 425. agar tidak rusak. ${ }^{19}$ Sementara itu, Ibn Fāris menjelaskan bahwa asal maknanya adalah memelihara sesuatu. ${ }^{20}$ Adapun kata al-Qur'an secara etimologis berasal dari kata qara'a yang menjadi mașdar bersama dengan kata al-qiräah. Sementara secara terminologis, al-Qur'an didefinisikan sebagai kalämullāh yang berupa mu'jizat, diturunkan kepada Nabi Muhammad saw. dan tertulis dalam mushaf-mushaf, diriwayatkan secara mutawattir serta membacanya merupakan ibadah. ${ }^{21}$

Secara definitif, kata Mujāhadah tahfiz alQur'an dalam artikel ini diartikan sebagai usaha dengan sungguh-sungguh atau jihad melalui alQur'an. sebuah usaha keras dengan kesungguhan yang kuat, bersungguh-sungguh dalam menggapai kualitas hafalan al-Qur'an yang baik, memelihara dan menjaganya. Mujahadah tahfidz al-Quran mulai diterapkan di PPI sejak tahun 2000 dengan dua bentuk mujahadah yaitu ula (tingkat pertama) dan tsaniah (tingkat kedua). Pada tahun 2015 ditambahkan jenis mujahadah yang baru sebagai pengembangan metode dan respon terhadap masalah sosial yang terjadi di PPI. Dengan demikian, hingga tahun 2017, PPI memiliki tiga bentuk mujahadah yaitu mujahadah ula (tingkat pertama), mujahadah tsaniah (tingkat kedua), dan mujahadah tsalitsah (tingkat ketiga) yang juga dikenal dengan sebutan mujahadah majlis alsyahadab karena fungsinya adalah sebagai syarat mendapatkan pengakuan telah menghafal seluruh al-Quran (syahadab).

19 Adib Bisri and Munawwir Abdul Fattah, Kamus Al-Bisri (Surabaya: Pustaka Progressif, 1999)., hlm. 123. Wazan suläsis mujarrad dipindahkan menjadi suläsis maẓid dengan cara menggandakan 'ain fi il-nya memiliki beberapa fungsi. Kata haffaza dalam konteks ini memiliki makna liddalälati 'ala at-taksisir yakni menghafalkan banyak ayat atau menghafalkan secara terus menerus sehingga banyak yang dihafalkan. Lihat Muhammad Ma'shum ibn 'Ali, Al-Amsilah at-Tașrifiyyah (Surabaya: Salim Nabhan, n.d.)., hlm. 12.

${ }^{20}$ Fāris, Mu’jam Al-Maqāyìs Fi Al-Lughah., hlm. 275. Bandingkan dengan Rāgīb Al-Așfahāni, Al-Mufradāt Fì Garìb Al-Qứān (Beirut: Dar al-Qalam, 1412)., hlm. 244 245.

21 Lihat Muhammad 'Abdul 'Aẓim Al-Żarqānī, Manāhil Al-'Irfän Fì 'Ulüm Al-Qur'Ān, I (Beirut: Dar alKutub al-'Ilmiyyah, 2010)., hlm. 14 - 17. 
Mujahadah tingkat pertama adalah Mujahadah Ula. Mujahadah ini diperuntukkan bagi para santri yang telah menghafal $30 \mathrm{Juz}$ al-Qur'an secara sempurna. ${ }^{22}$ Bentuk normatifnya adalah seorang santri diharuskan menghadap kepada guru secara langsung dalam ruangan tertentu (talaqqi wal musyafahab), tempat musyafahah bisa dilakukan di mushalla, ruangan kelas, atau di rumah guru tersebut. Talaqqi dilakukan setiap hari dan santri harus membaca al-Qur'an tanpa melihat (bil gaib, bil hifdzi) sebanyak satu juz dan disimak langsung oleh guru, santri-santri lainnya harus menunggu secara berbaris di belakang santri yang sedang membaca tersebut. Jika selesai membaca satu juz, santri akan mencium tangan gurunya dan mundur kemudian santri yang berbaris di belakangnya akan maju untuk menyimakkan hafalan, begitu seterusnya hingga santri terakhir.

Setelah selesai menyimakkan hafalan selama 30 hari atau 30 Juz, maka santri tersebut diharuskan kembali melakukan hal yang sama kepada lima guru lainnya. Guru yang berhak menyimak hafalan dalam mujahadah ula dibagi menjadi dua bagian yaitu guru untuk santri putra yaitu Ahmad Royani al-Hafidz ${ }^{23}$ menyimak sebanyak dua kali khatam, Ahmad Fuad al-Hafidz menyimak sebanyak dua kali khatam, dan Maryati al-Hafidzah. Sementara guru penyimak bagi santri putri adalah Ahmad Royani al-Hafidz, Muyassaroh al-Hafidzah, Daria al-Hafidzah, dan

22 LEMTATIQI, Buku Kegiatan Santri Tabfidh (Indralaya: Pondok Pesantren Al-Ittifaqiah, 2016), 16.

23 Penyebutan gelar al-Hafidz di belakang nama memiliki arti seorang yang telah menghafalkan al-Qur'an, Lihat Lisya Chairani and M.A. Subandi, Psikologi Santri Penghafal Al-Qur'an: Peranan Regulasi Diri (Yogyakarta: Pustaka Pelajar, 2010)., hlm. 38. Sementara itu, al-Hafidz yang diletakkan di depan nama seseorang memiliki menunjukan penggunaan gelar dalam terminologi hadits. Tingkatan al-häfiz dalam hadits lebih tinggi kedudukannya daripada Mubaddis. Di antara ulama yang mendapatkan gelar al-hāfiz dalam bidang hadits adalah 'Abd al-Rahmān ibn Mahdi (W. 298 H), Abū Nu'aim al-Faḍl ibn Żakwān (W. 209 H.), dan 'Abdullah ibn 'Abdirrahman al-Dārimī (W. 245 H.). Lihat Marwān Muhammad Muștāeāā Syāhīn and Musthafa Muhammad as-Sayyid Abū 'Imarah, Al-Manhal Ar-Rāwì Fì Ulümi Al-Hadìs an-Nabāwì (Kairo: Dar alThaba'ah al-Muhammadiyyah, 1982), 11 - 12.
Anis Sa'adah al-Hafidzah. Tujuan dari mujahadah ula, menurut Maryati, salah satu pembina LEMTATIQI dalam wawancara dengan penulis, adalah memperbaiki bacaan dan hafalan al-Qur'an (tabsin al-qira'ab wa al-tabfidø) serta persiapan santri untuk menghadapi mujahadah tsaniah atau mujahadah tingkat kedua. ${ }^{24}$

Mujāhadah yang kedua disebut mujāhadah śāniah. Maksudnya adalah mujāhadah yang dilakukan dengan cara berpuasa selama 40 hari dan setiap hari melantunkan al-Quran dengan hafalan atau tanpa melihat mushaf (bil gaib). Pembacaan al-Quran setiap hari tersebut dilakukan secara individual dan tidak disimak baik oleh santri lain ataupun pembina. Proses ini dilakukan setelah seorang santri menyelesaikan program mujāhadah ula dan diberi nasihat oleh pembina sebelum melakukan mujāhadah tingkat kedua, nasihat yang diberikan biasanya berupa peringatan, motivasi, dan panduan melakukan puasa 40 hari dan juga khatam (membaca 30 juz al-Quran) sebanyak 40 kali khataman. ${ }^{25}$ Setelah berhasil melewati tahapan kedua, maka para penghafal al-Quran di Pondok Pesantren AlIttifaqiah Indralaya akan melalui fase berikutnya atau mujahadah tingkat ketiga.

Mujahadah ketiga disebut mujahadah tsalitsah atau mujahadah majlis asy-syahadah. Penamaan tersebut merujuk pada fungsi mujahadah yang ketiga ini sebagai sarana ujian pemberian syahadah atau ijazah bagi santri yang mampu melewatinya. Pada tingkatan ini, seorang santri yang telah melalui dua proses sebelumnya akan membaca al-Qur'an bi al-ghaib sebanyak 30 Juz dalam satu ruangan khusus dengan cara disimak oleh seluruh santri dan pengajar. Jika santri tersebut dinyatakan lulus pada tingkatan ini, maka ia akan memperoleh syahädah atau ijazah sanad hafalan al-Qur'ān. Waktu maksimal menyelesaikan mujāhadah $\dot{s} a$ lis $\dot{a}$ b ini adalah 15 jam dan biasanya dimulai pada hari Kamis sore dan

24 Maryati (Pembina LEMTATIQI Putri), Wawancara, 25 Maret 2017.

25 Muyassaroh (Pembina LEMTATIQI), Wawancara, 05 Maret 2017.. 
selesai pada hari Jumat pagi atau siang dengan pembagian waktu istirahat secukupnya. ${ }^{26}$ Batasan kelulusan seorang santri adalah dua kali kesalahan jali pada setiap juznya (misal: benar-benar lupa hafalan ayat tertentu hingga perlu dibimbing oleh tim penyimak) atau secara kumulatif 60 kesalahan dalam membaca al-Quran 30 Juz.

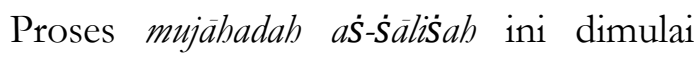
dengan sambutan dari unsur pimpinan (mudir) jika hadir pada saat pembukaan prosesnya. Dilanjutkan dengan wașilah dan kirim fatihah untuk para pengajar dan pembina, untuk PPI, dan juga untuk keperluan santri yang melakukan mujāhadah itu sendiri. Hal ini dipimpin langsung oleh pembina yang hadir seperti Ahmad Royani Abdul Mudi. Selanjutnya santri akan mulai membaca dari surat al-Fātiḥah hingga akhir. Para pembina menyimak secara bergantian pada awalnya, dan ketika bacaan santri mendekati juz 30, maka pembina akan mendampingi dan membacakan doa khatm al-Qur'än setelah kegiatan selesai.

\section{Landasan Normatif Tradisi Mujahadah: Dimensi Epistemologis}

Landasan normatif-teologis tradisi mujahadah ini dapat ditemukan dalam lembaran kaifiyah (tatacara) melaksanakan mujahadah 40 hari yang ditulis oleh KH. Nawawi Abdul Aziz Yogykarta Indonesia yang merupakan guru dari seluruh pembina LEMTATIQI. Lembaran kaifyah tersebut merupakan satu lembar kertas dengan tulisan aksara arab dalam bahasa jawa atau biasa dikenal dengan sebutan aksara arab pegon. Kaifiyah yang dimaksud adalah sebagai berikut:

\section{Kaifiyah Mujāhadah}

$$
\text { بسم الله الرحمن الرحيم }
$$

مجاهدة القرآن 40 دينا 40 ختمان ايكو اوتما باعت كدوى الرحى

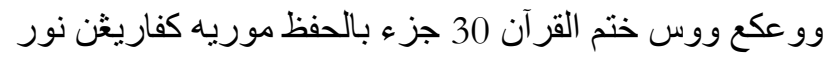

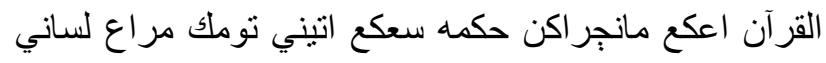
سهيعك القرآن ايكو تمباه تومنجف انجف اعدالم اتي لن تمباه اينطيع

26 Wahyudi Bin Sardin (Pembina LEMTATIQI kampus D), Wawancara, 17 Oktober 2016.
دواجااعدالم لسان سرتا عاصلاكن فيراع بركه. كنجع رسول

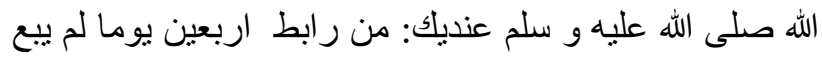

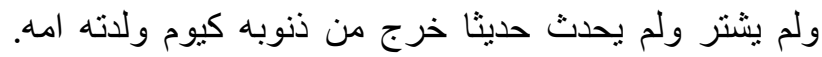

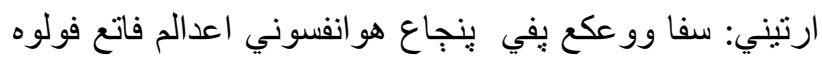

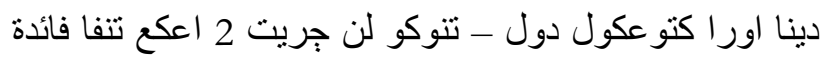

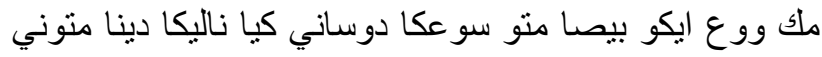

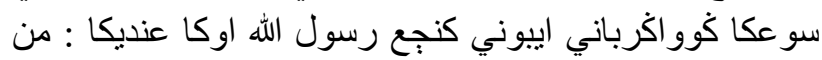

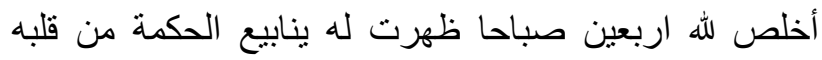

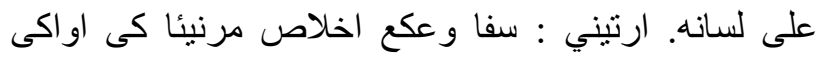

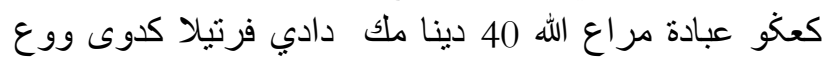

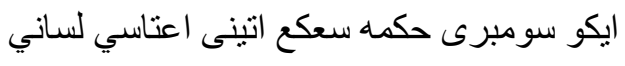

\section{كيفيه لن أدابي ميويتي مجاهدة}

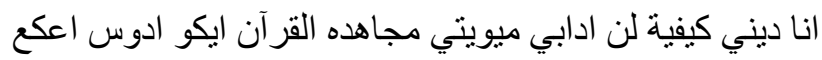

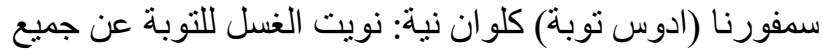

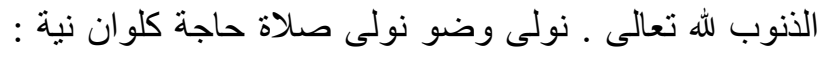

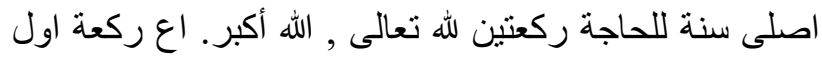

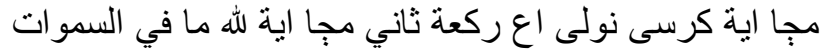

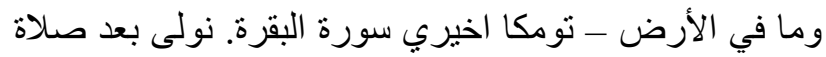

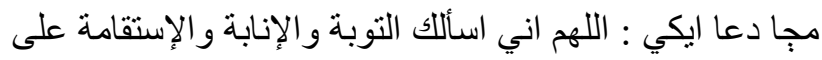

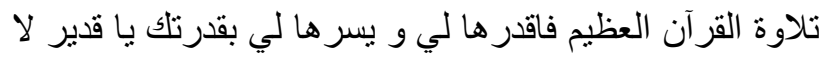

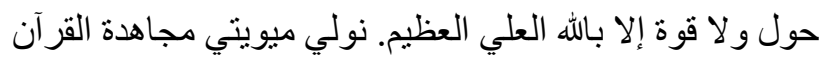

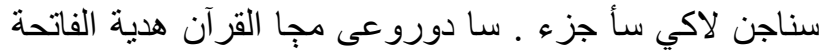
كاي اع عيسور ايكي: 1 - إلى حضرة النبي المصطفى رسول الله صلى الله الله عليه

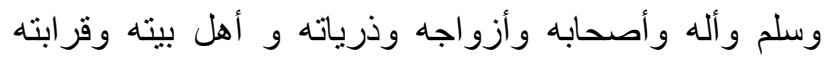
اجمعين , لهم الفاتحة.

2 - ثم ألى حضرة جميع الأنبياء و المرسلين و الملائكة

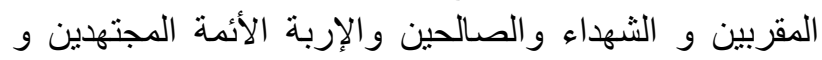

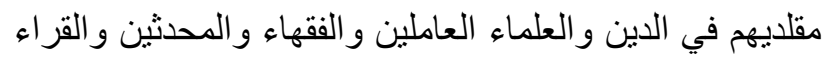
و المفسرين والسادات الصوفية و الاين المحقفين إلى ولى جميع اولياء

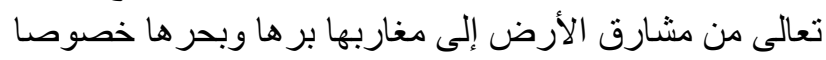

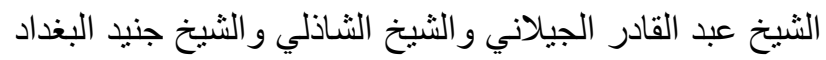

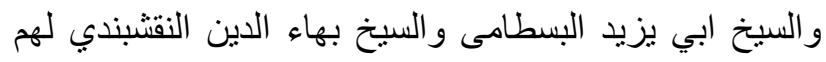

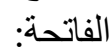

3 - ثم إلى أرواح ابائنا و امهاتنا و أجدادنا و جداتتا و إخوانتا

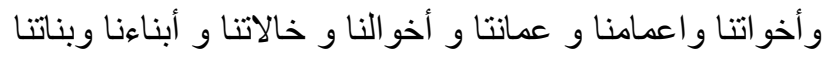

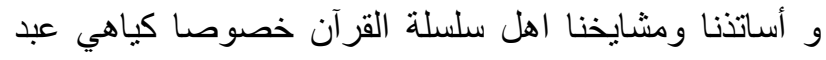

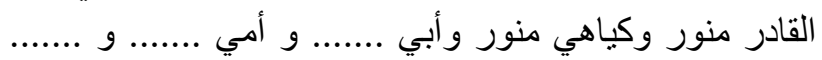
ل الهم الفاتحة. (اتو ا عاعكو هديه فاتحة لييا اعكع لويه جندك / داوا) الفقير إلى رحمة القادر : نووي عبد العزيز 


\section{Transliterasi:}

\section{Mujāhadah al-Quran \\ Bismillahirrahmanirrahim}

Mujāhadah al-Quran 40 dino 40 khataman iku utama banget keduwe wong kang wus khatam al-Quran $30 \mathrm{Juz}$ bil hifdzi mureh keparingan nur al-Quran ingkang mancaraken hikmah sangking atine tumeko marang lisane sahinggo al-Quran iku tambah tumancep ing dalem atine lan tambah enteng diwoco ing dalem lisan serto ngasilaken pirang-pirang berokah. Kanjeng Nabi saw. ngediko: man rabatha arba'ina yauman lam yabi' walam yastari wa lam yuhaddits haditsan kharaja min dzunubihi ka yaumin waladathu ummuhu. Artine sopo wong kang nyepi nyancang hawa nafsune ing dalem patang puluh dino ora ketungkul dol tinuku lan ceritacerita ingkang tonpo paidah moko wong iku biso metu songko dusone kaya nalika dino metu songko gua garbane ibune. Kanjeng rasulullah ugo ngendiko: man akhlasha lillahi arba'ina shabahan dzaharat lahu yanabi'al hikmati min qalbihi 'ala lisanihi. Artine: sopo wong kang ikhlas murniake awakke kanggo ngibadah marang Allah 40 dino moko dadi pertilo keduwe wong iku sumbere hikmah sangking atine ingatase lisane.

Kaifiyyah lan adabe miwiti mujāhadah

Onodene kaifiyah lan adabe miwiti mujāhadah al-Quran iku adus ing kang sempurno (adus taubat) kelawan niat: nawaitul gusla littaubati 'an jami'i al-dzunubi lillahi ta'ala. Nuli wudhu nuli shalat hajat kelawan niat: ushalli sunnatan lil hajati rak'ataini lillahi ta'ala, Allahu Akbar. Ing rokaat awwal moco ayat kursi nuli ing rokaat tsani moco ayat lillahi ma fi al-samawati wa ma fil ard - tumuko akhire surat al-baqarah. Nuli ba'da shalat moco du'a iki: allahumma inni as'aluka al-taubata wal inabata wal istiqamata 'ala tilawatil quranil adzimi faqdirha li wa yassirha li biqudratika ya qadiru la haula wa laa quwwata illa billahi al-aliyyi al-adzim. Nuli miwiti mujāhadah al-Quran sanajan lagi sa' juz. Sa' durunge moco al-Quran hadiah al-Fatihah ke ingkang ngisorake:
Ila hadrati al-Nabiyyi al-Mushthafa rasulillabi saw wa alibi wa ashabibi wa azwajibi wa dzurriyyatibi wa abli baitibi wa qarabatibi ajma'in, labum al-Fatihah.

Tsumma ila badrati jami'il anbiya wal mursalin wal malaikatil muqarrabin wa al-syuhada'i wa alShalibina wa al-Irbati al-aimmati al-mujtabidina wa muqallidibim fi al-din wal al-Ulama al-'Alimin wa alFuqaha wa al-Mubadditsina wal qurra'i wal mufassirina wa al-Sadaati al-Shufiyyati wal Muhaqqiqina ila jami'il auliya'i ta'ala min masyariq al-Ardi ila magharibiha barriha wa bahriba khushushan al-Syaikh Abdul Qadir al-Jilani wa al-Syaikh al-Syadrili wa al-Syaikh Junaid al-Bagdadi wa al-Syaikh Abi Yarid al-Busthami, wa alSyaikh Baba'uddin al-Naqsabandy. Lahum al-Fatibah.

Tsumma Ila Arwabi Aba'ina wa Ummahatina wa Ajdadina wa Jaddatina wa Ikbwanina wa Akbawatina wa A'mamina wa 'Ammatina wa Akhawalina wa Khalatina wa Abna'ina wa banatina wa ustadrina wa masyayikhina abli silsilatil qurani khushushan kyai Abdul Qadir Munawwir wa Kyai Munawwir wa Abi ..... wa Ummi .... wa .... labum alFatihah.

(Atawa nganggo hadiah al-Fatihah liya ingkang lewih cendak / dowo)

Al-Faqir ila rahmatil qadir: Nawawi Abdul Aziz.

\section{Terjemah:}

\section{Mujāhadah al-Quran \\ Bismillahirrahmanirrahim}

Mujāhadah al-Quran 40 hari 40 kali khatam itu sangat utama bagi orang yang telah mengkhatamkan al-Quran 30 juz bil hifdzi (dengan hafalan, tanpa melihat al-Quran). Tujuannya adalah agar mendapatkan cahaya al-Quran yang memancarkan hikmah dari hatinya melalui lisannya sehingga al-Quran itu lebih menancap dalam hatinya dan ringan dibaca oleh lisannya serta menghasilkan berbagai barokah. Nabi Muhammad saw. bersabda: man rabatha arba'ina yauman lam yabi' walam yastar wa lam yuhaddits haditsan kharaja min dzunubihi ka yaumin waladathu ummuhu. Artinya: barang siapa yang menyepi dan mengikat hawa nafsunya selama 40 hari, tidak sibuk dan berjual beli serta tidak berbicara yang tidak membawa faidah maka orang 
tersebut bisa keluar dari dosa-dosanya sebagaimana hari ketia ia dilahirkan dari rahim ibunya. Rasulullah SAW. juga bersabda: man akblasha lillabi arba'ina shabahan dzabarat labu yanabi'al hikmati min qalbihi 'ala lisanibi. Artinya barang siapa yang ikhlas memurnikan jiwanya untuk beribadah kepada Allah selama 40 hari maka akan tampak pada orang tersebut sumber hikmah dari hatinya melalui lisannya.

\section{Tatacara dan adab memulai mujahadah}

Adapun tatacara dan adabnya memulai mujāhadah al-Quran itu harus mandi yang sempurna (mandi taubat) dengan niat: nawaitul gusla littaubati 'an jami'i al-dzunubi lillabi ta'ala. Kemudian berwudhu' kemudian shalat hajat dengan niat: ushalli sunnatan lil hajati rak'ataini lillabi ta'ala, Allahu Akbar. Pada rakaat pertama membaca ayat kursi kemudian pada rakaat kedua membaca ayat lillahi ma fi al-samawati wama fil ardsampai akhirnya surat al-Baqarah kemudian setelah shalat membaca doa ini: allahumma inni as'aluka altaubata wal inabata wal istiqamata 'ala tilawatil quranil adzimi faqdirha li wa yassirha li biqudratika ya qadiru la haula wa laa quwwata illa billabi al-aliyyi al-adzim. Kemudian memulai mujahadah al-Quran walaupun hanya satu juz. Sebelum membaca al-Quran menghadiahkan al-Fatihah kepada yang dibawah ini:

Ila hadrati al-Nabiyyi al-Mushthafa rasulillahi saw wa alibi wa ashabibi wa azwajibi wa dzurriyyatibi wa abli baitibi wa qarabatibi ajma'in, labum al-Fatibah.

Tsumma ila hadrati jami'il anbiya wal mursalin wal malaikatil muqarrabin wa al-syubada'i wa alShalibina wa al-Irbati al-aimmati al-mujtahidina wa muqallidibim fi al-din wal al-'Ulama al-'Alimin wa alFuqaha wa al-Mubadditsina wal qurra'i wal mufassirina wa al-Sadaati al-Shufiyyati wal Mubaqqiqina ila jami'il auliya'i ta'ala min masyariq al-Ardi ila magharibiha barriba wa babriha khushushan al-Syaikh Abdul Qadir al-Jilani wa al-Syaikh al-Syadzili wa al-Syaikh Junaid al-Bagdadi wa al-Syaikh Abi Yazid al-Busthami, wa alSyaikh Baha'uddin al-Naqsabandy. Labum al-Fatihah.

Tsumma Ila Arwabi Aba'ina wa Ummahatina wa Ajdadina wa Jaddatina wa Ikbwanina wa
Akhawatina wa A'mamina wa 'Ammatina wa Akbawalina wa Khalatina wa Abna'ina wa banatina wa ustadrina wa masyayikebina abli silsilatil qurani khushushan kyai Abdul Qadir Munawwir wa Kyai Munawwir wa Abi ..... wa Ummi .... wa ..... lahum alFatihah.

(atau menggunakan hadiah fatihah lain yang lebih pendek atau lebih panjang)

Al-Faqir ila rahmatil qadir: Nawawi Abdul Aziz.

Dari kaifiyah di atas dapat dipahami bahwa adab atau tatacara memulai mujahadah adalah mandi taubat, shalat hajat dua rakaat di mana pada rakaat pertama membaca ayat kursi (QS. Al-Baqarah/2: 255) dan pada rakaat kedua membaca QS. Al-Baqarah/2: 284 - 286, setelah itu membaca doa berikut: allahumma inni as'aluka al-taubata wal inabata wal istiqamata 'ala tilawatil quranil adzimi faqdirha li wa yassirha li biqudratika ya qadiru la baula wa laa quwwata illa billabi al-aliyyi aladzim.

Setelah membaca doa dilanjutkan dengan mengirimkan hadiah al-Fātiḥah yang ditujukan kepada tiga tingkatan, yaitu Nabi saw. beserta keluarga, sahabat, istri, keturunan dan kerabatnya. Kedua, kepada para nabi dan rasul, malaikat, para syuhada', orang-orang shalih, para imam mujtahid dan pengikutnya, para ulama, ahli ilmu, ahli figh, ahli hadits, seluruh wali Allah dan juga secara khusus kepada para imam tarekat. Ketiga, kepada orang tua, saudara, para ustadz dan syaikh yang terdapat dalam jalur sanad serta secara khusus kepada KH. Abdul Qadir Munawwir dan juga KH. M. Munawwir serta hajat-hajat lainnya. Bacaan al-Fātihah tersebut bisa lebih diringkas atau lebih panjang sesuai dengan kebutuhan.

Dalam lembaran tersebut dijelaskan bahwa alasan pemilihan 40 hari adalah berdasarkan pada sabda Nabi Muhammad saw. "Barangsiapa yang mengikhlaskan dirinya untuk Allah selama 40 subuh maka akan terpancar butiran-butiran hikmah dari hatinya melalui lisannya".

Riwayat di atas dikutip oleh beberapa cendekiawan muslim abad pertengahan dalam 
berbagai karyanya. Di antara cendekiawan yang mengutip riwayat tersebut adalah Fakhruddīn arRāzi, ${ }^{27}$ Niẓamuddīn an-Naisābūri, ${ }^{28}$ Abū Zaid al$\dot{S}{ }^{a} l a b i,{ }^{29}$ dan juga Abū 'Abdillāh Muḥammad alMișri yang menuliskannya lengkap beserta sanad sebagai berikut: ${ }^{30}$

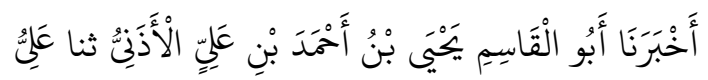

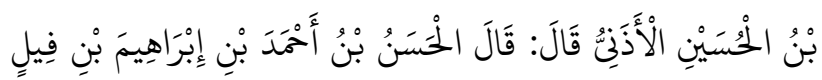

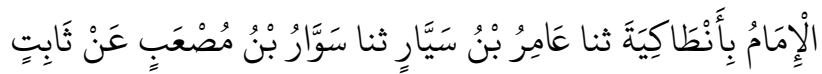

عَنْ مِقْسَمِ عَنْ ابْنِ عَبَّاسِ قَالَ: قَالَ رَسُولُ اللَّهِ صَلَّلَ اللهُ عَلَيِِِْ

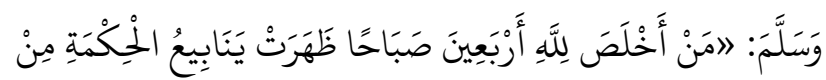

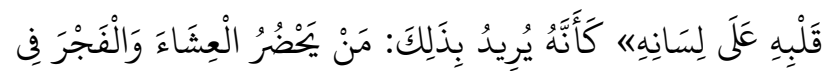

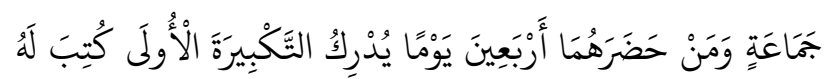

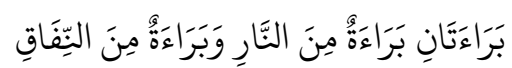

Telah mengabarkan kepada kami Abū alQāsim Yaḥyā ibn Aḥmad ibn 'Alī al-Ażanniy, telah menceritakan kepada kami 'Alī ibn al-Husain ia berkata, telah berkata al-Ḥasan ibn Aḥmad ibn Ibrāhīm ibn Fīl seorang imam di Antokia, telah mengabarkan kepada kami 'Āmir ibn Sayyār telah menceritakan kepada kami Sawwār ibn Muṣ’ab dari S̄ābit dari Miqsam dari ibn 'Abbās ia berkata: telah bersabda Rasulullah saw. "barang siapa yang mengikhlaskan (dirinya untuk beribadah) kepada Allah selama 40 subuh maka akan terpancar dari hatinya bitiran-butiran hikmah melalui lisannya" keolah-olah ia hendak mengatakan dengan ungkapa tersebut: "Barang siapa yang ikut shalat Isya dan Subuh dalam jama'ah dan menghadiri keduanya selama 40 hari dan mendapati takbir

${ }^{27}$ Lihat Fakhruddīn Ar-Rāzi, Mafätỉh Al-Gaib, XVI (Beirut: Dar Ihya al-Turats al-'Arabi, 1420), 154.

28 Niżamuddīn An-Naisābūri, Garāìb Al-Qur'ān Wa Ragāib Al-Furqān (Beirut: Dar al-Kutub al-'Ilmiyyah, 1416), 286.

29 Abū Zaid An-Naisābūri, Al-Jawāhir Al-Hisān Fī Tafsìr Al-Qur'ān, I (Beirut: Dar Ihya al-Turats al-'Arabi, 1418)., hlm. 219.

30 Abū 'Abdillāh Muḥammad ibn Salāmah AlMișri, Musnad Asy-Syihāb, I (Beirut: Muassasah Ar-Risalah, 1986), 285. yang pertama maka akan dicatatkan baginya dua keselamatan, yaitu: dari keselamatan dari api neraka dan keselataman dari kemunafikan.

Meskipun demikian, beberapa cendekiawan lain menyatakan bahwa riwayat tersebut memiliki derajat dha'if atau tidak valid sebagai sebuah landasan hukum dan tidak sampai jalur sanadnya sampai kepada Rasulullah. Beberapa cendekiawan yang menolak penggunaan hadits ini adalah Abū al-'Abbās Aḥmad alAnjāri, ${ }^{31}$ Majduddīn al-Jazari, ${ }^{32}$ dan Taqiyuddīn Abū al-'Abbās al-Dimasyqi. ${ }^{33}$ Walaupun beberapa cendekiawan menolak riwayat di atas, pembatasan angka 40 kerap digunakan dalam ajaran Islam dan juga disebutkan dalam berbagai hadits shahih. 40 hari merupakan angka perpindahan manusia dalam rahim dari satu kondisi ke kondisi yang lain, 40 hari juga menjadi batasan tidak diterima shalatnya seorang yang meminum khamr, al-Hāfiz 'Abdul Qādir ar-Ruhāwi menuliskan sebuah kitab yang berisi 40 hadits, dalam 40 bab, dan setiap bab memuat satu hadits yang menyebutkan angka $40 . .^{34}$

Hadits di atas juga kerap dikutip oleh para mufassir ketika mendiskusikan perintah Allah swt. kepada Nabi Musa ketika berniat menemui Tuhan-nya dan naik ke gunung selama 40 malam. Begitu pula penjelasan Abū 'Abdillāh Muhammad yang mengatakan bahwa maksud hadits ini adalah orang yang mengikuti shalat jama'ah isya' dan subuh selama 40 hari akan terbebas dari api neraka dan orang-orang munafik. 'Ali ibn Sulțān Muhammad mengatakan bahwa hitungan 40 itu cukup untuk mengubah manusia menuju ketaatan

31 Abū al-'Abbās Aḥmad Al-Anjāri, Al-Bahr AlMadìd Fì Tafsìr Al-Qur'ān Al-Majìd, II (Kairo: Hasan 'Abbās Zakiy, 1419), 255.

32 Majduddīn Al-Jazari, Jāmi' Al- 'Ușūl Fì Ahādìs Ar-Rasūl, XI (Kuwait: Maktabah Dar al-Bayan, 1972), 556.

33 Taqiyuddīn Abū al-'Abbās Ad-Dimasyqi, Jāmi' Al-Masāill Li Ibn Taimiyyah, VI (Makkah: Makkah: Dār 'Ālam al-Fawā'id, 1422), 133.

34 Ad-Dimasyqi., 134 - 135. 
ataupun kemaksiatan. ${ }^{35}$ Dengan demikian, meskipun landasan hadits yang dipakai adalah hadits dha'if, tetapi amaliyah 40 hari merupakan suatu tradisi yang telah dilakukan oleh para 'ulama. Maka dengan demikian, kegiatan mujāhadah selama 40 hari tetap mendapatkan legitimasinya di tengah masyarakat.

Jumlah halaman al-Quran jika menggunakan mushaf standar untuk penghafal alQur'an adalah 20 halaman untuk setiap juz. AlQuran terdiri dari 30 juz atau total 600 halaman dan setiap juz dapat diselesaikan dalam waktu 30 menit. 30 Juz al-Qur'an dapat dibaca dengan lancar selama 15 jam dengan pembagian sebagai berikut: bacaan dimulai sejak pukul 04.00 setelah melakukan shalat tahajjud dan sahur untuk puasa, jumlah juz yang dapat dibaca hingga waktu zuhur adalah 12 Juz. Setelah shalat zuhur digunakan untuk membaca 4 Juz dan setelah shalat ashar dibaca 4 juz, 10 juz akhir dibaca setelah shalat magrib dan diakhisri pada pukul 23.30. ${ }^{36}$

\section{Landasan Historis Tradisi Mujahadah: Perjalanan Panjang Sanad Tahfidz Al- Quran}

Jika dirujuk pada lembaran di atas, sebelum memulai tradisi mujahadah akan didahului dengan pengiriman fatihah kepada tiga tingkatan. yaitu Nabi SAW. beserta keluarga, sahabat, istri, keturunan dan kerabatnya. Kedua, kepada para nabi dan rasul, malaikat, para syuhada', orangorang shalih, para imam mujtahid dan pengikutnya, para ulama, ahli ilmu, ahli fiqh, ahli hadits, seluruh wali Allah dan juga secara khusus kepada para imam tarekat. Ketiga, kepada orang tua, saudara, para ustadz dan syaikh yang terdapat dalam jalur sanad serta secara khusus kepada KH. Abdul Qadir Munawwir dan juga KH. M. Munawwir serta hajat-hajat lainnya. Bacaan al-

35 Lihat 'Ali ibn Sulțān Muhammad, Mirqāt AlMafätih: Syarh Misykāt Al-Mașäbih, IX (Beirut: Dar al-Fikr, 2002), 2386.

36 Muyassaroh (Pembina LEMTATIQI), Wawancara, 05 Maret 2017.
Fātiḥah tersebut bisa lebih diringkas atau lebih panjang sesuai dengan kebutuhan.

Pada tingkatan pertama, pembacaan alFātiḥah ditujukan kepada Nabi saw. keluarga, shahabat, istri, keturunan, dan kerabatnya. Kedua, kepada para nabi dan rasul, malikat, para syuhada', orang-orang shalih, para imam mujtahid dan pengikutnya, para ulama, ahli ilmu, ahli fiqh, ahli hadits, seluruh wali Allah dan juga secara khusus kepada para imam thariqat. Ketiga, kepada orang tua, saudara, para ustadz dan syaikh yang terdapat dalam jalur sanad serta secara khusus kepada KH. Abdul Qadir Munawwir dan juga KH. M. Munawwir serta hajat-hajat lainnya. Bacaan al-Fātihah tersebut bisa lebih diringkas atau lebih panjang sesuai dengan kebutuhan.

Pada tingkatan kedua dikhususkan alFatihah untuk para ulama ahli tarekat yaitu: 1) Syaikh 'Abdul Qādir al-Jīlāni, 2) Syaikh Syażili, 3) Syaikh Junaid al-Bagdādi, 4) Syaikh Abū Yazīd alBisțāmi, dan 5) Syaikh Baha'uddīn anNaqsabandi.

Nama pertama yang disebutkan dalam kaifiyah adalah Syaikh 'Abdul Qādir al-Jīlāni. Di kalangan kaum sufi, Syaikh 'Abdul Qādir al-Jīlāni diakui sebagai ghauts atau quthb al-awliya, yang menduduki tingkat kewalian tertinggi. Nisbat alJīāni menunjukkan tempat kelahirannya yaitu di wilayah Gilan, Kurdistan Selatan dan berjarak 150 kilometer sebelah timurlaut kota Bagdad. Beliau meninggal dunia di Bagdad pada tahun 1166 (561 Hijriah). ${ }^{37}$ Tarekat ini masuk ke Indonesia lewat seorang tokoh sufi asal Aceh bernama Hamzah Fansyuri dan hingga kini menyebar luas di berbagai wilayah di Indonesia. ${ }^{38}$

Tokoh kedua adalah syaikh Syażili. Nama aslinya adalah Syaikh Abū al-Hasan 'Ali Syażili, seorang sufi kelahiran Gumara, Tunisia, sekitar tahun 593 H/1196 M. Beliau wafat di padang pasir Hitmaithira, Mesir, pada tahun $656 \mathrm{H} / 1258$

37 Martin Van Bruinessen, Kitab Kuning, Pesantren, Dan Tarekat: Tradisi-Tradisi Islam Di Indonesia (Bandung: Mizan, 1995), 210 - 211.

${ }^{38}$ Lihat Idrus Al-Kaf, Tasawuf Dan Mistisisme Islam (Palembang: Grafika Telindo Press, 2011), 186 - 187. 
M. ${ }^{39}$ Tarekat syaikh Syażili diikuti oleh beberapa ulama terkenal, salah satunya adalah imam Ibn 'Ațacillāh as-Sakandari, pengarang kitab al-Hikam. Hingga saat ini, tarekat syadziliah dan juga kitab al-Hikam masih tersebar luas di Indonesia, khususnya di Jawa. ${ }^{40}$

Nama selainjutnya adalah Syaikh Junaid al-Bagdādi. Syaikh Junaid memiliki nama asli Abū Qāsim Muḥammad ibn Muḥammad ibn al-Junaid al-Bagdādi. Beliau lahir, tinggal, dan wafat di Bagdad pada tahun 297 H (910 M). Syaikh Junaid terkenal sebagai seorang sufi dan diakui keilmuannya dalam bidang tauhid dan tasawwuf, beliau juga menekankan pentingnya berpegang pada al-Qur'an dan sunnah dalam menjalankan tasawwuf. Mengenai hal ini, beliau mengatakan: ${ }^{41}$

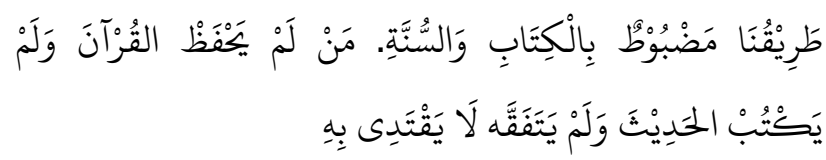

"Jalan (tarekat) kami dibatasi (dikontrol, sesuai) dengan al-Quran dan Sunnah. Barangsiapa yang tidak hafal al-Quran dan tidak menulis hadits serta tidak faham masalah fiqh, maka ia tidak patut diikuti."

Nama keempat adalah Syaikh Abū Yazīd al-Bisțāmi. Nama lengkapnya adalah Abū Yazīd Ṭaifūr ibn 'Īsā ibn Syarwasān al-Bisțāmi. ${ }^{42}$ Beliau merupakan ulama tasawwuf yang wafat pada tahun $261 \mathrm{H} .^{43}$ Idrus Al-Kaf menyatakan bahwa nama al-Bisțāmi dan al-Bagdādi menunjukkan dua jenis kecenderungan dalam tasawwuf yaitu kecenderungan Khurasani dan 'Iqi. Ajaran alBisțāmi bersifat ghalabah (menekankan ketidak-

39 A. Aziz Masyhuri, Ensiklopedi 22 Aliran Tarekat Dalam Tasawuf (Surabaya: Imtiyaz, 2014), 303.

40 Al-Kaf, Tasawuf Dan Mistisisme Islam, 191 - 192.

41 Lihat Khairuddīn Az-Zarkāsyi, Al-A'lam, II (Beirut: Dar al-'Ilm lil Malāyīn, 2002)., hlm. 141.

42 Dalam Wafayàt al-A'yān disebutkan bahwa namanya adalah Abū Yazīd Ṭaifur ibn 'T̄sā ibn Ādam ibn 'İsā ibn 'Ali al-Baștāami. Nisbah Basthami menunjukkan daerah Bastham, Khurasan dekat Iraq saat ini. Lihat Abū al'Abbās Syamsuddīn Al-Barmaki, Wafayāt Al-A'yān Wa Anba'u Abnāi Az-Zaman, II (Beirut: Dār Șādir, 1900), 531.

43 Syamsuddīn Abū 'Abdillāh Muhammad AżŻahabi, Siyār A'làm an-Nubala', XIII (Beirut: Muassasah ArRisalah, 1985), 89. sadaran, ectasy) dan sukr (intoxication). Sedangkan ajaran al-Bagdādi menekankan pada aspek kesabaran (shahw, sobriety). ${ }^{44}$

Nama terakhir yang disebutkan dalam kaifiyah adalah Syaikh Baha'uddīn anNaqsabandi. Nama aslinya adalah Syaikh Muḥammad ibn Muhammad Baha'uddīn anNaqsabandi yang bertempat tinggal di Bukhara, Asia Tengah. Tarekat ini diperkenalkan di Indonesia oleh Syaikh Yusuf al-Makassari. ${ }^{45}$ Tidak ada keterangan yang pasti tentang alasan penyebutan kelima tokoh tersebut dalam kaifiyah memulai mujāhadah, akan tetapi kelima tokoh tersebut merupakan tokoh-tokoh tarekat yang telah banyak menyebar di Indonesia.

Secara substansial, tradisi mengkhatamkan al-Quran dalam hitungan waktu tertentu ini telah biasa dilakukan oleh Nabi Muhammad, para shahabat dari abad I - III H (abad 7 - 9 M), dan juga diteruskan oleh para ulama setelahnya hingga saat ini. ${ }^{46}$ Di Indonesia, tradisi ini juga dilestarikan oleh para ulama penghafal al-Quran seperti Kyai Muhammad Munawwir bin Kyai 'Abdullāh Rosyad, seorang syaikh tahfiz al-Qur'ān di Indonesia, selama tinggal di Makkah senantiasa mengkhatamkan al-Qur'an. Selama tiga tahun beliau mengkhatamkan al-Qur'an setiap satu

${ }^{44}$ Lihat Al-Kaf, Tasawnf Dan Mistisisme Islam., 184.

45 Al-Kaf., hlm. 188 Lihat juga Karel A. Steenbriknk, Beberapa Aspek. Tentang Islam Di Indonesia Abad Ke-19 (Jakarta: Bulan Bintang, 1984)., hlm. 178. Selain menjelaskan ajaran tarekat naqsabandiyah, Yusuf alMakassari juga kerap mengutip pendapat ulama tasawuf lain seperti: al-Gazāli, Ibn al-'Arabi, al-Jinni, dan Ibn 'Atha'illāh. Lihat Azyumardi Azra, Jaringan Ulama Timur Tengah Dan Kepulauan Nusantara Abad XVII \& XVIII: Melacak AkarAkar Pembaruan Pemikiran Islam Di Indonesia (Bandung: Ikappi, 1994), 232.

46 Imam al-Nawāwiy mengutip beberapa riwayat yang menjelaskan bahwa Ibn al-Kātib pernah mengkhatamkan al-Qur'an delapan kali dalam sehari semalam. Beliau juga mengutip riwayat Manșūr ibn Jidān yang mampu mengkhatamkan al-Qur'an antara waktu zuhur dan 'ashar, dan dua kali khatam antara magrib dan isya', hal yang sama juga dilakukan oleh Mujāhid, 'Ali al-Azadi, dan Sa'ad ibn Abī Waqāṣ. Akan tetapi imam an-Nawāwiy mengkritik riwayat yang pertama dan menyatakan bahwa hal itu adalah bentuk hiperbola (mubälagab). Yahya ibn Syarafuddīn An-Nawāwi, At-Tibyān Fì Adabi Hamalati AlQur'an (Beirut: Dār al-Nafācis, 1992), 45 - 48. 
minggu, tiga tahun berikutnya mengkhatamkan alQur'an setiap tiga hari, tiga tahun berikutnya mengkhatamkan al-Qur'an satu hari sekali dan ditambah dengan membaca al-Qur'an tanpa henti (kecuali untuk shalat dan ibadah) selama 40 hari sehingga mulutnya mengeluarkan darah. ${ }^{47}$

Selain itu, alur sanad yang dipaparkan dalam syahadah yang diberikan bagi santri yang berhasil menyelesaikan tiga tingakan mujahadah menunjukkan adanya pergeseran alur sanad secara geografis. Alur transmisi geografis tersebut dimulai dari Makkah dan Madinah pada masa Nabi dan shahabat, kemudian dibawa menuju Kufah oleh Abū 'Abdirrahmān al-Sullamiy dan beralih ke Mesir melalui Țāhir ibn Galbūn, kemudian sempat beredar di Spanyol (Cordova, Andalusia) melalui Abū Bakr 'Uśmān ibn Sa'īd ad-Dāni dan kembali lagi ke Mesir melalui jalur Abū al-Qāsim asy-Syāțibiy. Sanad tersebut beredar di Mesir selama beberapa generasi hingga Syaikh 'Abd al-Karim membawanya ke Makkah sebelum bertemu dengan Kyai Munawwir yang membawa sanad tersebut ke Yogyakarta, Indonesia.

\section{Reward dan Cita-cita Tradisi Mujahadah: Dimensi Aksiologis}

Sebagai motivasi dan penghargaan bagi para santri dan pembina yang mampu melakukan Mujahadah, maka Pondok Pesantren Al-Ittifaqiah memberikan reward untuk setiap tingkatan. Pada tingkatan pertama atau mujahadah ula, setiap santri yang mampu menyelesaikan tahapan ini akan diberi reward Rp. 2.000.000 (dua juta rupiah), sementara para pembina yang mengikuti tahapan ini diberi reward Rp. 3.000 .000 (tiga juta rupiah). Metode mujahadab ula ini meniscayakan adanya quality control bagi hafalan setiap santri dengan cara disimak langsung oleh lima guru secara bergantian

${ }^{47}$ Lihat Pondok Pesantren Krapyak, Riwayat Hidup K.H.M. Moenaumir (Yogyakarta: Pondok Pesantren alMunawwir Krapyak, 2011)., hlm. 35. Hal ini juga dijelaskan oleh Abdul Jalil (Pembina Tahfidz. Pondok Pesantren alMunauwwir), Wawancara, 31 Maret 2017. sebanayak $30 \mathrm{Juz}$, selain itu, metode ini juga diperkuat dengan adanya reward di atas.

Reward yang diberikan oleh Pondok Pesantren Al-Ittifaqiah bagi santri yang mampu menyelesaikan mujahadah tingkat kedua adalah Rp. 3.000.000., sementara pembina yang mampu menyelesaikan mujahadah ini diberi reward $\mathrm{Rp}$. 4.000.000. Reward tersebut merupakan salah satu penghargaan dan motivasi yang diberikan selain tujuan utamanya yaitu memperlancar hafalan, menyempurnakan hafalan sehingga benar-benar menyatu di dalam hati para penghafalnya dan meringankan lidah dalam membaca al-Qur'an serta menjadi sarana latihan bagi santri untuk melanjutkan program mujahadah ketiga. ${ }^{48} \mathrm{KH}$. Muslim Nawawi, pimpinan pondok pesantren An-Nur Yogyakarta, menyatakan bahwa tujuan utama mujahadah ini adalah agar seorang santri senantiasa membaca al-Qur'an. ${ }^{49}$ Metode tikrar atau mengulangi secara konsisten selama 40 hari ini akan memberikan kebiasaan bagi santri untuk senantiasa membaca dan mengulangi pelajaran, khususnya dalam menghafal al-Qur'an.

Reward yang diberikan bagi para santri dan pembina yang mampu menyelesaikan mujahadah majlis asy-syahadah adalah diberikan syahadah atau ijazah bukti seorang santri telah membaca alQuran Qira'at (cara baca) imam 'Ashim dan riwayat imam Hafsh secara keseluruhan 30 Juz dan disimak oleh para guru yang memiliki mata rantai sanad bersambung hingga Nabi Muhammad saw. Implikasinya adalah legalitas pengajaran tahfidz dan bagi santri yang telah memiliki syahadah tersebut. Selain itu, PPI juga memberikan reward lain berupa tiket ibadah umroh ke Makkah bagi santri dan pembina yang berhasil menyelesaikan ketiga tingakatan mujahadah.

Ketiga bentuk mujahadah di atas dapat menjadi metode pembelajaran alternatif dan berkualitas khususnya bagi santri penghafal al-

48 Ahmad Royani (Ketua Lembaga LEMTATIQI), Wawancara, 05 Maret 2017.

49 KH. Muslim Nawawi (Pimpinan Pondok Pesantren An-Nur Yogyakarta), Wawancara, 23 Maret 2017. 
Quran di Indonesia dan di negara-negara lainnya. Metode ini dapat memecahkan permasalahan normatif-teologis tentang sulitnya menjaga hafalan yang selama ini tidak begitu disoroti oleh beberapa program tabfidz yang berkembang di Indonesia. Metode ini dapat pula digunakan sebagai media pembelajaran lainnya, tentunya dengan berbagai modifikasi sesuai dengan kondisi sosio-kultural dimana metode ini akan diterapkan.

\section{PENUTUP}

Dari pemarapan di atas, dapat disimpulkan tiga poin utama tingkatan mujahadah yang diterapkan di Pondok Pesantren AlIttifaqiah, Indralaya, Ogan Ilir, Sumatera Selatan, sebagai berikut:

1. Tingkatan pertama disebut mujahadah ula yaitu media quality-control dimana seorang santri yang telah menyelesaikan hafalan al-Quran secara sempurna (30 juz/600 halaman) diharuskan menyimakkan hafalannya kepada lima pembina lain yang ada di PPI.

2. Tingkatan kedua disebut mujahadah tsaniah yaitu media pembiasaan di mana seorang santri yang telah menyelesaikan mujahadah ula diharuskan berpuasa selama 40 hari dan selama itu mengkhatamkan al-Qur'an sebanyak 40 kali tanpa membaca (bil gaib). Setiap hari mengkhatamkan al-Qur'an.

3. Tingakatan ketiga disebut mujahadah tsalitsah atau mujahadah majlis asy-syahadah dimana santri yang telah melalui dua tingkatan sebelumnya akan diuji dengan cara membaca al-Quran secara utuh 30 juz tanpa melihat selama 15 jam dan disimak oleh seluruh santri dan pembina dalam majlis khusus.

Penulis memberikan saran kepada segenap pembina lembaga tabfidr, dan khususnya pembina Rumah Tahfidz yang jumlahnya semakin menjamur dewasa ini, untuk menerapkan tradisi mujahadah sebagai sarana menjaga hafalan alQuran. Dengan demikian, penghafalan al-Qur'an bukan hanya proses memindahkan al-Qur'an ke dalam hafalan setiap individu, tetapi menjadikan
al-Qur'an sebagai bagian dari keseharian dan senantiasa dibaca setiap waktu. Wallabu A'lam.

\section{DAFTAR KEPUSTAKAAN}

'Ali, Muhammad Ma'shum ibn. Al-Amsilah atTashrifiyyah. Surabaya: Salim Nabhan, n.d.

Ad-Dimasyqi, Taqiyuddīn Abū al-'Abbās. Jāmi' Al-Masāíl Li Ibn Taimiyyah. VI. Makkah: Dār 'Ālam al-Fawā'id, 1422.

Al-Anjāri, Abū al-'Abbās Ahmad. Al-Bahr AlMadìd Fì Tafsìr Al-Qur'ān Al-Majīd. II. Kairo: Hasan 'Abbās Zakiy, 1419.

Al-Ashfahāni, Rāgīb. Al-Mufradāt Fì Garīb AlQur'ān. Beirut: Dar al-Qalam, 1412. - Mu'jam Al-Mufradāt Fì Garì Al-Qur'an. Beirut: Dar al-Qalam, 1412.

Al-Bāqi, Muhammad Fu'ād 'Abd. Al-Mu'jam AlMufahras Li Alfadri Al-Qur'an. Beirut: Dar alFikr, 1994.

Al-Barmaki, Abū al-'Abbās Syamsuddīn. Wafayāt Al-A'yān Wa Anba'u Abnāi Az-Zaman. II. Beirut: Dār Shādir, 1900.

Al-Bukhari, Abu Abdillah Muhammad ibn Isma'il. Al-Musnad Al-Shabih Al-Mukbtashar Min Umuri Rasulillab Saw Wa Sunanibi Wa Ayyamibi. Vol. VI. Beirut: Dar Thauq AnNajah, 1422.

Al-Gazāliy, Abū Hāāmid. Ihyà 'Ulūm Al-Dìn. V. Kairo: Dar al-Hadits, n.d.

Al-Jazari, Majduddīn. Jāmi’ Al-Ushuñl Fì Abādìs Ar-Rasūl. XI. Kuwait: Maktabah Dar alBayan, 1972.

Al-Kaf, Idrus. Tasawuf Dan Mistisisme Islam. Palembang: Grafika Telindo Press, 2011.

Al-Mishri, Abū 'Abdillāh Muhammad ibn Salāmah. Musnad Asy-Syihāb. I. Beirut: Muassasah Ar-Risalah, 1986.

Al-Żarqānī, Muhammad 'Abdul 'Adziim. Manāhil Al-Irfān F̄̀ Ulüm Al-Qur'Ān. I. Beirut: Dar al-Kutub al-'Ilmiyyah, 2010.

Ali, Atabik, and Ahmad Zuhdi Muhdlor. Kamus Al-Ashri. Yogyakarta: Multi Karya Grafika, 1996.

Amin, Muhammad. "Tradisi Mujahadah Tahfidz Al-Quran Di Pondok Pesantren Al-Ittifaqiah 
Indralaya Ogan Ilir Sumatera Selatan (Analisis Living Quran)." Dirosat: Journal of Islamic Studies 2, no. 2 (2017): 138-44.

An-Naisābūri, Abū Zaid. Al-Jawāhir Al-Hisān Fì Tafsì Al-Qur'ān. I. Beirut: Dar Ihya al-Turats al-'Arabi, 1418.

An-Naisābūri, Niżamuddīn. Garā'ib Al-Qur'ān Wa Raga’ib Al-Furqān. Beirut: Dar al-Kutub al'Ilmiyyah, 1416.

An-Nawāwi, Yaḥya ibn Syarafuddīn. At-Tibyān Fì Adabi Hamalati Al-Qur'an. Beirut: Dār alNafācis, 1992.

Ar-Rāzi, Fakhruddīn. Mafātih Al-Gaib. XVI. Beirut: Dar Ihya al-Turats al-'Arabi, 1420.

As, Asmaran. Pengantar Studi Tasawwuf. Jakarta: Raja Grafindo Persada, 1996.

Aż-Żahabi, Syamsuddīn Abū 'Abdillāh Muhammad. Siyār A'läm an-Nubala'. XIII. Beirut: Muassasah Ar-Risalah, 1985.

Az-Zarkāsyi, Khairuddīn. Al-A'lam. II. Beirut: Dar al-'Ilm lil Malāyīn, 2002.

Azra, Azyumardi. Jaringan Ulama Timur Tengah Dan Kepulauan Nusantara Abad XVII \& XVIII: Melacak Akar-Akar Pembaruan Pemikiran Islam Di Indonesia. Bandung: Ikappi, 1994.

Bisri, Adib, and Munawwir Abdul Fattah. Kamus Al-Bisri. Surabaya: Pustaka Progressif, 1999.

Bruinessen, Martin Van. Kitab Kuning, Pesantren, Dan Tarekat: Tradisi-Tradisi Islam Di Indonesia. Bandung: Mizan, 1995.

Chairani, Lisya, and M.A. Subandi. Psikologi Santri Penghafal Al-Qur'an: Peranan Regulasi Diri. Yogyakarta: Pustaka Pelajar, 2010.

Fāris, Zakariyya ibn. Mu'jam Al-Maqāyìs Fi AlLughah. Beirut: Dar al-Fikr, 1994.

Gade, Anna M. Perfection Makes Practice: Learning, Emotion, and the Recited Quran in Indoensia. USA: University of Hawai, 2004.

Hayati, Nurhasanah, and Oktarina Yusra. "Fenomena Lansia Menghafal Al-Quran Pada Majelis Al-Quran Di Kec. Salimpaung Kab. Tanah Datar Sumatera Barat." Fuaduna: Jurnal Kajian Keagamaan Dan Kemasyarakatan 02, no. 02 (2018): 64-65.
Hikmawati. "Bimbingan Tahfidz Al-Quran: Studi Tentang Stategi Penghafal Al-Qur'an Di Pondok Pesantren Qudratullah KM. 35 Langkan Kabupaten Banyu Asin"." UIN Raden Fatah Palembang, 2013.

Koentjaraningrat. Pengantar Ilmu Antropologi. Jakarta: Rineka Cipta, 2009.

LEMTATIQI. Mengenal Lembaga Tabfidh Tilawah Dan Ilmu Al-Qur'an AlIttifaqiah,. Indralaya: Ittifaqiah Press, 2006.

Masyhuri, A. Aziz. Ensiklopedi 22 Aliran Tarekat Dalam Tasawuf. Surabaya: Imtiyaz, 2014.

Moelong, Lexy J. Metodologi Penelitian Kualitatif No Title. Bandung: Rosdakarya, 2016.

Muḥammad, 'Ali ibn Sulțān. Mirqāt Al-Mafätib: Syarh Misykāt Al-Mașābih. IX. Beirut: Dar alFikr, 2002.

Munawwir, Ahmad Warson. Al-Munawwir: Kamus Arab - Indonesia. Surabaya: Pustaka Progressif, 1997.

Pondok Pesantren Krapyak. Riwayat Hidup K.H.M. Moenaumir. Yogyakarta: Pondok Pesantren al-Munawwir Krapyak, 2011.

Ratna, Nyoman Kutha. Metodologi Penelitian: Kajian Budaya Dan Ilmu Sosial Humainiora Pada Umumnya No Title. Yogyakarta: Pustaka Pelajar, 2010.

Romadoni, Ali. "Tradisi Hafalan Qur'an Di Masyarakat Indonesia." Journal of Qur'an and Hadith Studies 4, no. 1 (2015): 14.

Steenbriknk, Karel A. Beberapa Aspek Tentang Islam Di Indonesia Abad Ke-19. Jakarta: Bulan Bintang, 1984.

Steingass, F. Arabic - English Dictionary. New Delhi: Cosmo Publication, 1978.

Syāhīn, Marwān Muhammad Muștạ̄āā, and Musthafa Muhammad as-Sayyid Abū 'Imarah. Al-Manbal Ar-Rāwì Fì Ulùmi AlHadìs an-Nabāwì. Kairo: Dar al-Thaba'ah alMuhammadiyyah, 1982.

Taufik, dkk. Kumpulan Drikir Dan Do'a Kafa Bibi. Bantul: Pondok Pesantren An-Nur, 2015.

Taufik, Muhammad. "Studi Al-Qur'an Sebagai Pemicu-Pemacu Peradaban: Telaah Sosio- 
Hostoris." Fuaduna: Jurnal Kajian Keagamaan

Dan Kemasyarakatan 03, no. 02 (2019): 13435.

\section{Wawancara}

Abdul Jalil (Pembina Tabfidz Pondok Pesantren al-Munawwir), Wawancara, 31 Maret 2017.

Ahmad Royani (Ketua LEMTATIQI), Wawancara, 05 Maret 2017.

KH. Muslim Nawawi (Pimpinan Pondok Pesantren An-Nur Yogyakarta), Wawancara, 23 Maret 2017.

Muyassaroh (Pembina LEMTATIQI), Wawancara, 05 Maret 2017.

Wahyudi Bin Sardin (Pembina LEMTATIQI), 17

Oktober 2016. 